\title{
Efficacy of Crotoxyphos Sprays for the Control of the Southern Cattle Tick in Puerto Rico ${ }^{1}$
}

\author{
Glen I. Garris and John E. George ${ }^{2}$
}

\begin{abstract}
Field trials were conducted near Cabo Rojo and Mayagüez, Puerto Rico, to evaluate the efficacy of crotoxyphos (alpha-methylbenzyl 3-hydroxycrotonate dimethyl phosphate) applied as a whole-body spray to cattle for control of the southern cattle tick, Boophilus microplus (Canestrini). Percent control was determined by comparing numbers of 4.5 - to 8.0 -mm-sized engorged females present on control and treated animals on days $0,1,7,14$, and 21 posttreatment. Crotoxyphos at concentrations of 0.49 to $0.015 \%$ a.i. afforded an average control in excess of $92 \%(92.9$ to $99.8 \%)$ for all concentrations. Differences in percent control of ticks between concentrations and also between days on which counts were made were determined by analysis of variance to be statistically nonsignificant.
\end{abstract}

\section{INTRODUCTION}

Puerto Rico was officially declared free from infestation by the southern cattle tick, Boophilus microplus (Canestrini), in June 1953 (5), but in 1978, B. microplus was reported by the USDA Animal and Plant Health Inspection Service (APHIS), Veterinary Services (VS), infesting cattle near Utuado, Puerto Rico. Since its reintroduction, this species has rapidly spread and become well established throughout the island, including Vieques and possibly Culebra. Also in 1978, the USDA placed a quarantine on the movement of cattle from Puerto Rico to mainland areas of the U.S., and the Commonwealth government in cooperation with APHIS, VS, initiated an eradication campaign against this tick species.

The eradication effort is based on the use of currently recommended and registered acaricides, of which only crotoxyphos (alpha-methylbenzyl 3 -hydroxycrotonate dimethyl phosphate) and crotoxyphos plus dichlorvos (2,2-dichlorovinyl dimethyl phosphate) have approved labels for the control of ticks on lactating dairy cattle (10). Crotoxyphos ${ }^{3}$ is the official acaricide being used by APHIS, VS, on lactating dairy animals in the present eradication campaign. It is effective for the control of the south-

${ }^{1}$ Manuscript submitted to Editorial Board March 26, 1982.

${ }^{2}$ Research Entomologist, USDA, S\&E, ARS, Tropical Tick Research Laboratory, Tropical Agriculture, Research Station, Mayagüez, P.R.; and Research Leader, Tick Research Unit, U.S. Livestock Insects Laboratory, ARS, S\&E, USDA, Kerrville, TX.

${ }^{3}$ This paper reports the results of research only. Mention of a pesticide does not constitute a recommendation for use by the USDA nor does it imply registration under FIFRA as amended. Also, mention of a commercial or proprietary product in this paper does not constitute an endorsement by the USDA or the Agricultural Experiment Station of the University of Puerto Rico. 
ern cattle tick in the Caribbean (8,9), in Mexico and Texas (1, 2, 4), and in Brazil (7). However, no data are available on the effect of crotoxyphos in field tests for control of the southern cattle tick in Puerto Rico. We report in this paper the results of four field tests of the efficacy of six concentrations of crotoxyphos against the southern cattle tick in Puerto Rico.

\section{MATERIALS AND METHODS}

The tests were conducted at two dairies located in the Cabo Rojo area and one dairy located in Mayagüez. The first test was begun July 1980, and the last test was completed April 1981, the period of the year roughly corresponding to the end of the rainy season and early part of the dry season.

For the four separate tests conducted, 15 lactating Holstein dairy cows were used in Tests 1 and 2; 25 lactating Holstein dairy cows were used in Test 3; and 45 Holstein dairy heifers were used in Test 4. The animals were divided into five groups, and animals within groups for each test were of similar age and size. The level of infestation of the southern cattle tick on each animal was determined by making counts on each animal of all engorging female ticks that were between 4.5 and $8 \mathrm{~mm}$ in length. A metal gauge similar to the one described by Wharton et al. (11) was used. Ticks were counted at $0,1,7,14$, and 21 days posttreatment. The technique described by Wharton et al. (11) for evaluating the efficacy of an acaricide against larvae, nymphs, and adults on the host at the time of treatment was used in this study.

Percent control was calculated by using the following equation (6) which takes into account variation in populations of ticks on treated and untreated animals before and after application of the acaricide (3):

$$
\% \text { Control }=100\left[1-\left(\frac{\mathrm{Ta} \times \mathrm{Cb}}{\mathrm{Tb} \times \mathrm{Ca}}\right)\right]
$$

$\mathrm{Ta}=$ Average number of ticks on treated cattle after treatment;

$\mathrm{Tb}=$ Average number of ticks on treated cattle before treatment;

$\mathrm{Ca}=$ Average number of ticks on untreated cattle after treatment; and

$\mathrm{Cb}=$ Average number of ticks on untreated cattle before treatment.

Because all the ticks counted on an animal on a given day dropped off the host within $24 \mathrm{hr}$, after a count was made, it was ssumed that each count was a separate event. The percent control values calculated for each acaricide concentration were subjected to a square root transformation, and the transformed data were analyzed by analysis of variance (11).

The four concentrations of crotoxyphos, diluted from a $25 \%$ a.i. emul- 
sifiable concentrate (EC), used in Tests 1,2 , and 3 were $0.49,0.24,0.12$, and $0.06 \%$. An attempt was made in Test 4 to determine the concentration of crotoxyphos that would afford less than $90 \%$ control, and thus concentrations of $0.24,0.06,0.03$, and $0.015 \%$ a.i. were tested. All concentrations were obtained by mixing the concentrate with water on a weight/volume basis. Samples of the acaricide mixtures were taken before and after each treatment and shipped to the APHIS Veterinary Services Diagnostic Laboratory in Ames, Iowa, for chemical analysis to determine actual concentrations.

Each of four equal groups, three animals per group in Tests 1 and 2, 5 animals per group in Test 3, and 9 animals per group in Test 4, were hand sprayed with crotoxyphos with a power sprayer at $1379 \mathrm{kPa}$; a fifth group of animals in each test served as controls. About 10 liters of the acaricide mixture was applied to each animal. Control animals were kept separated from treated animals until after the treated animals had partially dried, except in Tests 3 and 4 , when the control animals were kept separated for 24 hours. All animals were then returned to the same pasture and normal operational procedures of each dairy.

The acaricide and power spray equipment [a 20 gal (757 liters) John Beam $^{(1)}$ sprayer] used were obtained from APHIS, VS, and are the normal equipment and commercial-grade acaricide being used in the tick eradication program in Puerto Rico.

\section{RESULTS AND DISCUSSION}

Differences between the results of the first three tests were not statistically significant and were pooled for presentation (table 1). A high degree of control was obtained with all the crotoxyphos concentrations tested, but $100 \%$ was not achieved even with $0.49 \%$ a.i. The degree of control calculated for a given day actually is an evaluation of the effect of the crotoxyphos on various life stages; for example, female ticks were 4.5 to $8 \mathrm{~mm}$ on day 21 post-treatment had been attached larvae on the day the cattle were treated. Percent controls as determined on days 1, 7, 14 , or 21 were not statistically different. Also, even though the highest percent control was associated with the highest concentration of acaricide, the differences in control between concentrations were not statistically significant. The fourth trial (table 1) was an attempt to determine the extent to which the crotoxyphos can be diluted before it ceases to provide more than $90 \%$ control. The lowest concentration tested, $0.015 \%$ a.i., gave about the same percent control as $0.49 \%$ a.i.

In previous tests with other formulations of crotoxyphos, Drummond and co-workers $(1,4)$ showed that sprays of 0.15 and $0.32 \%$ afforded $>99 \%$ control of IR (Index of Reproduction), but $0.075 \%$ afforded only $93.19 \%$ control of B. microplus. Mello et al. (7) applied crotoxyphos as 
TABLE 1.-Control of Boophilus microplus on lactating Holstein cows (Tests 1-3) or Holstein heifers (Test 4) with sprays of crotoxyphos

\begin{tabular}{|c|c|c|c|c|c|c|c|c|c|c|}
\hline \multirow{3}{*}{$\begin{array}{c}\text { Concentration } \\
\text { of } \\
\text { Crotoxyphos }\end{array}$} & \multicolumn{9}{|c|}{ Data $^{1}$ obtained at indicated days post-treatment } & \multirow{3}{*}{$\begin{array}{c}\text { Mean } \\
\text { Control }^{2}\end{array}$} \\
\hline & \multirow{2}{*}{$\begin{array}{c}\text { Day } 0 \\
\text { Mean } \\
\text { number } \\
\text { \&/animal }\end{array}$} & \multicolumn{2}{|c|}{ Day 1} & \multicolumn{2}{|c|}{ Day 7} & \multicolumn{2}{|c|}{ Day 14} & \multicolumn{2}{|c|}{ Day 21} & \\
\hline & & $\begin{array}{c}\text { Mean } \\
\text { number } \\
\text { f/animal }\end{array}$ & Control & $\begin{array}{c}\text { Mean } \\
\text { number } \\
\text { \&/animal }\end{array}$ & Control & $\begin{array}{c}\text { Mean } \\
\text { number } \\
\text { q/animal }\end{array}$ & Control & $\begin{array}{c}\text { Mean } \\
\text { number } \\
\text { \&/animal }\end{array}$ & Control & \\
\hline$\%$ & & & $\%$ & & $\%$ & & $\%$ & & $\%$ & $\%$ \\
\hline \multicolumn{11}{|c|}{ Tests 1-3 } \\
\hline Control & 201 & 191 & - & 213 & - & 121 & - & 73 & - & - \\
\hline 0.49 & 174 & $<1$ & 99.8 & 0 & 100 & 1 & 99 & 1 & 98.4 & 99.3 \\
\hline .24 & 155 & 1 & 99.3 & 1 & 99.4 & 2 & 97.9 & 1 & 98.2 & 98.7 \\
\hline .12 & 168 & 3 & 98.1 & 4 & 97.7 & 12 & 88.1 & 4 & 93.4 & 94.3 \\
\hline .06 & 183 & 8 & 95.3 & 5 & 97.4 & 15 & 86.4 & 5 & 92.5 & 92.9 \\
\hline \multicolumn{11}{|c|}{ Test 4} \\
\hline Control & 37 & 69 & - & 65 & - & 38 & - & 119 & - & - \\
\hline 0.240 & 63 & $<1$ & 99.4 & 0 & 100 & $<1$ & 99.9 & 0 & 100 & 99.8 \\
\hline .060 & 51 & $<1$ & 99.1 & 0 & 100 & 0 & 100 & $<1$ & 99.7 & 99.7 \\
\hline .030 & 47 & 1 & 98.9 & $<1$ & 99.6 & $<1$ & 99.1 & $<1$ & 99.9 & 99.4 \\
\hline .015 & 40 & 2 & 97.5 & 1 & 98.4 & $<1$ & 98.4 & $<1$ & 99.4 & 98.4 \\
\hline
\end{tabular}

${ }^{1}$ Mean number $=$ whole-body counts of all females 4.5 to $8 \mathrm{~mm}$ in length.

${ }^{2}$ Differences in the average percent control for the four acaricide concentrations tested were not statistically significant. 
0.075 and $0.1 \%$ sprays to cattle infested with $B$. microplus and calculated the percentage reduction from counts of all stages of ticks attached to two $10-\mathrm{cm}$ areas on each animl on days 7,14 , and 21 post-treatment. For both concentrations, control was $>92 \%$ on days 7 and 14; and, in contrast to our results, on day 21 control at 0.075 and $0.1 \%$ was only 53.4 and $74.9 \%$, respectively. We interpret the low percentage reduction obtained by Mello et al. at day 21 to be due to a difference in the methods used to evaluate the efficacy of this acaricide. We observed many ticks attached to the test animals on day 21 , but few were within the 4.5 - to $8-\mathrm{mm}$ category.

The results of these tests of crotoxyphos indicate that it is effective over a wide range of concentrations, and a 10-fold dilution did not make a statistically significant difference in the present control obtained. Although the use of larger sample sizes would probably demonstrate a significant dosage effect, our results with a limited number of cattle failed. to reveal one.

The normal concentration of crotoxyphos used in the eradication program by APHIS, VS, is $0.49 \%$. Our results show that sprays of 0.49 to $0.25 \%$ should provide $>95 \%$ control. Chemical analysis of samples of the acaricide mixtures by the APHIS, VS Diagnostic Laboratory verified. that the crotoxyphos in each of the four tests was applied at the desired. rate. Even though we did not obtain $100 \%$ control with any of the application rates tested, one positive attribute of crotoxyphos is that in a tick eradication or control program even relatively large dilution errors would make little difference on the level of mortality obtained with a treatment.

\section{RESUMEN}

Pruebas de campo cerca de Cabo Rojo y Mayagüez, Puerto Rico, se llevaron a cabo para evlaluar la eficacia de "crotoxyphos" $\alpha$-metilbenzil 3hidroxicrotonate dimetil fosfato rociado sobre todo el cuerpo del ganado para el control de la garrapata del sur, Boophilus microplus (Canestrini). Se determinó el porcentaje de control comparando el número de hembras hartas de sangre, 4.5 a $8.0 \mathrm{~mm}$, presentes en los animales de control y en los tratados, a $0,1,7,14$, y 21 días después del tratamiento. El "crotoxhyphos" en concentraciones de 0.49 a $0.015 \%$ i.a. produjo un control medio en exceso de $92 \%$ (92.9 a 99.8\%) en todas las concentraciones. Las diferencias en el porcentaje de control de garrapatas entre las concentraciones y también entre los días en los cuales se hicieron las lecturas, no fueron significtivas estadísticamente, según los análisis de la varianza. 


\section{LITERATURE CITED}

1. Drumond, R. O., 1973. Boophilus annulatus and B. microplus: Laboratory tests of insecticides, J. Econ. Entomol. 66: 130-33.

2. —- Ernst, S. L., Trevino, J. L., Gladney, W. J. and Graham, O. H., 1972. Boophilus annulatus and B. microplus: Sprays and dips of insecticides for control on cattle, J. Econ. Entomol. 65: 1354-57.

3. - and Gladney, W. J., 1978. Acaricides applied to cattle for control of the Lone Star tick, Southwest. Entomol. 3: 96-105.

4. - Graham, O. H., Ernst, S. E. and Trevino, J. L., 1967. Evaluation of insecticides for the control of Boophilus annulatus (Say) and B. microplus (Canestrini) [Acarina: Ixodidae] on cattle. Proc. 2nd Int. Cong. Acarol. 493-8.

5. Graham, O. H. and Hourrigan, J. L., 1977. Eradication programs for the arthropod parasites of livestock, J. Med. Entomol. 13: 629-58.

6. Henderson, C. F. and Tilton, E. W., 1955. Tests with acaricides against the brown wheat mite, J. Econ. Entomol. 48: 157-61.

7. Mello, D., Queiroz, S. C. and Madureira, F., 1968. Verificação preliminar do efeito Carrapaticida do Fenitrothion, Ciodrin e Chlorfenvinphos, contra o Boophilus microplus, Can 1888, em bovinos. O Biológico 34: 33-5.

8. Rawlins, S. C. and Mansingh, A., 1978. Acaricidal susceptibility of five strains of Boophilus microplus from four Caribbean countries, J. Econ. Entomol. 71: 142-44.

9. —, 1978. Patterns of resistance to various acaricides in some Jamaican populations of Boophilus microplus. J. Econ. Entomol. 71: 956-60.

10. Schwartz, P. H. and Hamel, D. R. (Ed), 1981. Guidelines for control of insect and mite pests of foods, fibers, feeds, ornamentals, livestock, households, forests and forest products, USDA, Agric. Handbook No. 571.

11. Wharton, R. H., Roulston, W. J., Utech, K. B. W. and Kerr, J. D., 1970. Assessment of the efficiency of acaricides and their mode of application against the cattle tick Boophilus microplus, Aust. J. Agric. Res. 21: 985-1006. 